\title{
A Study on Bacteriological Profile of Urinary Tract Infection in Diabetes Mellitus Patients in a Tertiary Care Hospital
}

\author{
B. Natesan ${ }^{1 *}$ and Thasneem Banu ${ }^{2}$ \\ ${ }^{1}$ Institute of Microbiology, Madras Medical College and RGGGH, Chennai, Tamil Nadu, India \\ ${ }^{2}$ Institute of Microbiology, MMC and RGGGH, Chennai, Tamil Nadu, India \\ *Corresponding author
}

\begin{tabular}{|c|c|}
\hline & A B S T R A C T \\
\hline & act Infection (UTI) is an inflamm \\
\hline Keywords & $\begin{array}{l}\text { invasion that is usually associated with bacteriuria and pyuria. UTI is upto three times } \\
\text { more common in diabetic than in non- diabetic women and increases with age. Urine from }\end{array}$ \\
\hline $\begin{array}{l}\text { UTI, Diabetic } \\
\text { patients, Drug } \\
\text { resistance, } \\
\text { Imipenem, E. coli }\end{array}$ & $\begin{array}{l}60 \text { diabetic patients with UTI was collected and subjected to Gram staining, culture \& } \\
\text { sensitivity by routine methods. Among Diabetic patients, the males constituted } 51.66 \% \\
\text { and were predominant. The maximum number of isolates was present in } 51-60 y r s \text { with } \\
35 \% \text { and next was } 41-50 y \text { rs age group with } 20 \% \text {.In Diabetes mellitus, E. coli was the }\end{array}$ \\
\hline Article Info & $\begin{array}{l}\text { predominant isolate with } 36.6 \% \text { followed by Klebsiella spp, Pseudomonas spp \& } \\
\text { Acinetobacter spp. In Diabetes patients, Imipenem, Amikacin and Nitrofurantoin had }\end{array}$ \\
\hline $\begin{array}{l}\text { Accepted: } \\
\text { 23 June } 2017 \\
\text { Available Online: } \\
\text { 10 July } 2017\end{array}$ & $\begin{array}{l}\text { greater sensitivity than other antibiotics. In Gram positive cocci isolated from Diabetic } \\
\text { patients, Amikacin and cephalexin had a greater sensitivity. This alarmingly high } \\
\text { resistance rate has to be approached cautiously, by formulating an antibiotic drug policy. } \\
\text { This has to include giving effective drugs after the culture \& sensitivity and ensuring that }\end{array}$ \\
\hline & the patients receive full course of antibiotic \\
\hline
\end{tabular}

\section{Introduction}

Urinary Tract Infection (UTI) is an inflammatory response of the urothelium to bacterial invasion that is usually associated with bacteruria and pyuria. Urinary tract is the second most common site for bacterial infection in human. Bacterial virulence factors play a subsidiary part in the genesis of disease.

UTI refer to those infections that occur in the presence of anatomic or functional abnormalities in the kidney, bladder or collecting systems; obstruction to normal urine flow (including renal, ureteric and bladder calculi and Benign Prostatic
Hypertrophy); cystic renal disease; specific diseases like Diabetes Mellitus and abnormalities in host defense mechanisms and those infections that follow surgery or procedures done in urinary tract.

UTI is upto three times more common in diabetic than in non- diabetic women and increases with age.

Many factors that predispose the diabetic patient to infections in the urinary tract have been described. Diabetes mellitus is associated with increased risk of these infections as a result of poorly controlled 
plasma glucose concentrations, which in turn may impair granulocyte function and cellmediated immunity. Also, the neurologic dysfunction associated with diabetic neuropathy may result in a neurogenic bladder with incomplete bladder emptying, urinary stasis, and retention. The increased likelihood of urethral instrumentation may predispose these patients to infection, as may diabetic microangiopathy, which can contribute to local ischemia and impaired host defences (Rayfield EJ et al., 1982, Wheat et al., 1980).

Asymptomatic bacteriuria has been described as occurring two to four times more frequently in diabetic woman (Wheat et al., 1980; Forland, 1977) and as being more prevalent in diabetic women than men (Kass et al., 1956). Other renal parenchymal complications of UTI in diabetic patients include Pyelonephritis, Emphysematous pyelonephritis, papillary necrosis and Perinephric abscesses; these conditions should be considered in the evaluation of nonresponse to appropriate antibiotic therapy for urinary infection in diabetic patients.

Most of the bacteria responsible for urosepsis in diabetics are Gram-negative rods, with E. coli and Klebsiella spp, accounting for about $70 \%$. Klebsiella spp are isolated twice as frequently in diabetic patients with bacteremic urinary infections, and a large proportion of these patients had indwelling urinary bladder catheters.

Madras Medical College and Rajiv Gandhi Government Hospital Chennai is a tertiary care hospital and a referral centre to the hospitals in the surrounding districts. Knowledge of the microbial organisms and antibiotic susceptibility pattern of Diabetic patients with UTI is essential for defining empirical treatment. Hence the present study focuses on the bacteriological profile and its resistance patterns in cases of UTI in Diabetic patients for a better clinical approach.

The main objectives of this study includes: To determine the Bacteriological profile in Diabetic patients with Urinary Tract Infection. To determine the Antibiotic susceptibility pattern using Kirby Bauer Disc diffusion method. And to analyse the drug resistant pattern in uropathogens in Diabetic patients with UTI.

\section{Materials and Methods}

\section{Sample collection}

\section{Midstream urine specimens}

Urine samples were most commonly collected by sampling the midstream flow by the clean - catch technique. Urine collection from women by this technique requires personal supervision for best results.

\section{Laboratory methods}

\section{Urine microscopic analysis}

Five $\mathrm{ml}$ of the urine specimen was centrifuged at $2500 \mathrm{rpm}$. Supernatant was removed and sediment used for microscopy analysis. The sediment was transferred on the clean slide and viewed for the presence of epithelial cells, red cells and casts.

\section{Gram staining}

Gram staining of urine smear was done and the presence of Gram negative bacilli or Gram positive cocci was initially observed. The presence of pus cells were also noted.

\section{Urine culturing and bacterial identification}

One $\mathrm{ml}$ of diluted (1/1000) urine specimen was used for culturing on CLED, Blood, and 
Mac Conkey agar. Specimen was inoculated using a calibrated loop. The plate was incubated at $35^{\circ} \mathrm{C}$ for $24 \mathrm{hrs}-48 \mathrm{hrs}$.

Specimens with more than $10^{5}$ colony forming unit [CFU]/ $\mathrm{ml}$ were considered as positive samples. The isolates were identified based on colony morphology on culture plates, Gram's staining and by standard biochemical tests. Antibiotic susceptibility testing was done by standard methods according to CLSI guidelines.

\section{Antimicrobial susceptibility testing}

Antibiotic susceptibility testing was performed by the Kirbey Bauer disc diffusion method on MHA (Mueller Hinton Agar) according to CLSI protocols. The diameters of zone of inhibition were interpreted according to CLSI standards for each organism. Media and disks were tested for quality control with standard strains.

\section{Results and Discussion}

The study undertaken at the Institute of Microbiology, Madras Medical College, Chennai among samples received from Diabetic patients of Rajiv Gandhi Government General Hospital, Chennai with UTI showed the following results. Sixty patients were included in this study.

Among diabetic patients, the males constituted $51.66 \%$ and were predominant. The male to female prevalence ratio is 1.06: 1 (Table 1). This was in comparison with the study conducted by Sibi et al., (2011) where the males were affected with UTI more than women in Diabetic patients.

In Gram positive cocci (GPC) isolated from Diabetic patients, Amikacin and cephalexin had a greater sensitivity. The majority of the patients presented with dysuria and was found in $37.5 \%$ patients. The next presentation was with fever in 30.8\%; followed by pain abdomen, frequency of micturition, hematuria, and oliguria in the decreasing order of presentation. These symptoms were comparable with the study by Mahesh et al., (Mahesh et al., 2010).

The E. coli was the commonest organism isolated with $36.6 \%$ (Table 3). The study conducted by Sibi et al., (2011) also had E. coli accounting for $39.14 \%$ and another study reported $47 \%$ of $E$. coli in their isolate (Andy et al., 2003). These results were in comparison with the present study.

The Klebsiella pneumoniae 20\%, Klebsiella oxytoca 5\%, Pseudomonas aeruginosa $11.6 \%$, Acinetobacter spp 10\%, Staphylococcus aureus $6 \%$ and Citrobacter freundii 5\% and Enterococcus faecalis 5\% were the other isolates in these diabetic patients (Table 3). The study by Sibi et al., (2011) had Klebsiella spp $15.7 \%$ which was comparable to this study.

The E. coli isolated in these patients had higher sensitivity $90.9 \%$ for Amikacin and $81.80 \%$ for Nitrofurantoin. But the resistance to cephalosporins and Fluoroquinolones were high, $75 \%$ and $80 \%$ respectively. The Imipenem was $100 \%$ sensitive (Table 4). Shill et al., (2010) in his study also reported 66\% resistance to cepholosporins $79 \%$ resistance to Fluoroquinolones; $3 \%$ resistance to Amikacin and $11.9 \%$ resistance to Nitrofurantoin and $100 \%$ sensitive to Imipenem. This study results were similar to the present study. Yet the resistance pattern to Cephalosporins and Fluoroquinolones in these patients is highly alarming and Amikacin and Imipenem offer promise in treating these $E$. coli infected Diabetes mellitus patients.

The Pseudomonas aeruginosa was the third commonest isolate in these patients. They were $42.8 \%$ sensitive to Amikacin and 
Cephalosporin, $14.2 \%$ sensitive to Fluroquinolones (Table 4).

In a similar study by Mahesh et al., (2010) $74.5 \%$ resistance rate to Fluoroquinolones and $64.7 \%$ resistance to Amikacin and Gentamicin were noted for Pseudomonas spp.
This was in comparison to the present study. In the present study, Pseudomonas spp were $100 \%$ sensitive to Imipenem whereas $70 \%$ of the isolates were sensitive to Carbapenems in the study by Mahesh et al., This is not coherent with the present study.

Table.1 Gender distribution in diabetes mellitus

\begin{tabular}{|l|c|c|}
\hline \multicolumn{1}{|c|}{ Gender } & Male & Female \\
\hline No of patients & 31 & 29 \\
\hline Percentage & $51.66 \%$ & $48.33 \%$ \\
\hline
\end{tabular}

Table.2 Distribution of patients with diabetes mellitus according to age group [ $\mathrm{n}=60$ ]

\begin{tabular}{|l|c|l|}
\hline Age groups & No of patients & Percentage \\
\hline $12-20$ & 6 & $10 \%$ \\
\hline $21-30$ & 4 & $6 \%$ \\
\hline $31-40$ & 7 & $11.6 \%$ \\
\hline $41-50$ & 12 & $20 \%$ \\
\hline $51-60$ & 21 & $35 \%$ \\
\hline $61-70$ & 4 & $6 \%$ \\
\hline $71-80$ & 6 & $10 \%$ \\
\hline Total & 60 & \\
\hline
\end{tabular}

The maximum number of isolates were present in 51-60yrs with 35\% and next was 41-50yrs age group with $20 \%$

Table.3 Uropathogens isolated in diabetes mellitus

\begin{tabular}{|l|c|c|}
\hline Name of the organisms & No of patients & Percentage \\
\hline E.coli & 22 & $36.6 \%$ \\
\hline K pneumoniae & 12 & $20 \%$ \\
\hline K oxytoca & 3 & $5 \%$ \\
\hline Pseudomonas aeruginosa & 7 & $11.6 \%$ \\
\hline Acinetobacter spp & 6 & $10 \%$ \\
\hline Citrobacter freundii & 3 & $5 \%$ \\
\hline Staph.aureus & 4 & $6 \%$ \\
\hline Enterococcus faecalis & 3 & $5 \%$ \\
\hline Total & 60 & \\
\hline
\end{tabular}

In Diabetes mellitus, E. coli was the predominant isolate with $36.6 \%$ followed by Klebsiella spp, Pseudomonas spp and Acinetobacter spp. 
Table.4 Gram negative bacilli - antibiotic sensitivity in diabetes mellitus patients ( $\mathrm{n}=53$ )

\begin{tabular}{|c|c|c|c|c|c|c|c|c|c|c|c|c|}
\hline \multirow{3}{*}{ Antibiotics } & \multicolumn{12}{|c|}{ Name of the Organisms } \\
\hline & \multicolumn{2}{|c|}{$\begin{array}{l}\text { E. coli } \\
\mathrm{n}=22\end{array}$} & \multicolumn{2}{|c|}{$\begin{array}{l}\text { Klebsiella } \\
\text { pneumoniae } \\
\mathrm{n}=12\end{array}$} & \multicolumn{2}{|c|}{$\begin{array}{l}\text { K.oxytoca } \\
\mathrm{n}=3\end{array}$} & \multicolumn{2}{|c|}{$\begin{array}{l}\text { Pseudomonas } \\
\text { aeruginosa } \\
\mathrm{n}=7\end{array}$} & \multicolumn{2}{|c|}{$\begin{array}{l}\text { Acineto } \\
\text { bacter spp } \\
\mathrm{n}=6\end{array}$} & \multicolumn{2}{|c|}{$\begin{array}{l}\text { Citro } \\
\text { bacter } \\
\text { freundii } \mathrm{n}=3\end{array}$} \\
\hline & No & $\%$ & No & $\%$ & No & $\%$ & No & $\%$ & No & $\%$ & No & $\%$ \\
\hline Amikacin & 20 & $90.9 \%$ & 6 & $50 \%$ & 3 & $\begin{array}{l}100 \\
\%\end{array}$ & 3 & $42.8 \%$ & 6 & $100 \%$ & 3 & $100 \%$ \\
\hline Nitrofurantoin & 18 & $81.8 \%$ & 6 & $50 \%$ & - & - & - & -- & 2 & $33.3 \%$ & 3 & $100 \%$ \\
\hline Norfloxacin & 4 & $18.1 \%$ & 3 & $25 \%$ & 1 & $\begin{array}{l}33.3 \\
\%\end{array}$ & 3 & $42.8 \%$ & 3 & $50 \%$ & 3 & $100 \%$ \\
\hline Ceftazidime & 7 & $31.8 \%$ & 3 & $25 \%$ & 3 & $00 \%$ & 3 & $42.8 \%$ & 4 & $6.6 \%$ & 3 & $100 \%$ \\
\hline Ciprofloxacin & 2 & $9.09 \%$ & 1 & $8.3 \%$ & - & - & 1 & $14.2 \%$ & 2 & $33.3 \%$ & 3 & $100 \%$ \\
\hline Ofloxacin & 4 & $18.1 \%$ & 3 & $25 \%$ & - & - & - & - & 2 & $33.3 \%$ & 3 & $100 \%$ \\
\hline Cotrimoxazole & 9 & $40.9 \%$ & - & - & 1 & $\begin{array}{l}33.3 \\
\%\end{array}$ & 1 & $14.2 \%$ & 1 & $16.6 \%$ & - & - \\
\hline Gentamicin & 4 & $18.1 \%$ & 3 & $25 \%$ & 3 & $\begin{array}{l}100 \\
\%\end{array}$ & 3 & $42.8 \%$ & 6 & $100 \%$ & - & - \\
\hline Imipenem & 22 & $100 \%$ & 12 & $\begin{array}{l}100 \\
\%\end{array}$ & 3 & $\begin{array}{l}100 \\
\%\end{array}$ & 7 & $100 \%$ & 6 & $100 \%$ & 3 & $100 \%$ \\
\hline
\end{tabular}

In Diabetes patients, Imipenem, Amikacin and Nitrofurantoin had greater sensitivity than other antibiotics.

Table.5 Gram positive cocci - antibiotic sensitivity in diabetes mellitus patients $(\mathrm{n}=7)$

\begin{tabular}{|l|l|l|}
\hline \multicolumn{1}{|c|}{ Antibiotics } & $\begin{array}{c}\text { Staphylococcus } \\
\text { aureus [n=4 ] }\end{array}$ & \multicolumn{1}{|c|}{$\begin{array}{c}\text { Enterococcus. faecalis } \\
{[\mathbf{n}=3]}\end{array}$} \\
\hline Amikacin & $3[75 \%]$ & $2[66.6 \%]$ \\
\hline Amoxy-clavulanic acid & $2[50 \%]$ & $2[66.6 \%]$ \\
\hline Erythromycin & - & - \\
\hline Cephalexin & $2[50 \%]$ & - \\
\hline Amoxycillin & $1[25 \%]$ & - \\
\hline Cotrimoxazole & $1[25 \%]$ & - \\
\hline Ciprofloxacin & $2[50 \%]$ & - \\
\hline Nitrofurantoin & - & $3[100 \%]$ \\
\hline
\end{tabular}

Out of the Gram positive cocci isolated, Staphylococcus aureus constituted the majority followed by Enterococcus faecalis. Staphylococcus aureus was found to be sensitive to Amikacin $(75 \%)$ and Cephalexin $(50 \%)$ and resistant to cotrimaxazole, amoxicillin and Ciprofloxacin. Enterococcus faecalis was found to be $66.6 \%$ sensitive to
Amikacin and amoxyclavulanic acid and $100 \%$ to Nitrofurantoin.

The poorly controlled glucose concentration may lead to decreased granulocyte function and cellular immunity. Diabetic neuropathy results in urinary stasis. Diabetic microangiopathy leads to impaired host 
defenses. All these reasons contribute to the colonization of these resistant uropathogens.

To summarise, Among Diabetic patients, the males constituted $51.66 \%$ and were predominant.

The maximum number of isolates was present in 51-60yrs with $35 \%$ and next was 41-50yrs age group with $20 \%$ (Table 2). In Diabetes mellitus, E. coli was the predominant isolate with $36.6 \%$ followed by Klebsiella spp, Pseudomonas spp and Acinetobacter spp.

In Diabetes patients, Imipenem, Amikacin and Nitrofurantoin had greater sensitivity than other antibiotics. In GPC isolated from Diabetic patients, Amikacin and cephalexin had a greater sensitivity.

This alarmingly high resistance rate has to be approached cautiously, by formulating an antibiotic drug policy. This has to include giving effective drugs after the culture and sensitivity and ensuring that the patients receive full course of antibiotics.

An ongoing surveillance of UTI should be encouraged for an updated knowledge about the uropathogens causing infection and their antibiotic resistance pattern to keep the medical community informed about the emerging antibiotic resistance.

\section{References}

Andy I.M. Hoepelman et al., Pathogenesis and management of bacterial urinary tract infections in adult patients with diabetes mellitus. International Journal of Antimicrobial Agents 22 [2003] S3543.

Bahrani- Mougeot FK, Buckles EL, Lockatell $\mathrm{CV}$, et al., Type I fimbriae and extracellular polysaccharides are preeminent uropathogenic Escherichia coli virulence determinants in the murine urinary tract. Mol Microbiol. 2002;45;1079-1093.

Bailey and Scott's Diagnostic Microbiology 12th edition chapter -57 , page $845-850$.

Forland M, Thomas V, Shelokov A. Urinary tract infections in patients with diabetes mellitus. Studies on antibody coating of bacteria. JAMA 1977;238:1924.

Gilbert DN, Urinary tract infections in patients with chronic insufficiency. Clin J Am Soc Nephrol. 2006;1:327-331.

Godaly G,Hang L, Frendeus B, et al., Transepithelial neutrophil migration is CXCRI dependent in vitro and is defective in IL-8 receptor knockout mice. J Immunol.2000;165;5287-5294.

Guyer DM, Henderson IR, Nataro JP, et al., identification of sat, an autotransporter toxin produced by uropathogenic Escherichia coli, Mol Microbiol. 2000; 38;53-66.

Hacker J, Kaper JB. Pathogenicity islands and the evolution of microbes, Annu Rev Microbiol. 2000;54; 641-679.

Hackley RH. A 25 year prospective morality study in the spinal cord injury patient: comparison with the long-term living paraplegic. J Urol 1977; 117: 486.

Hansson S, Martinell J, Stokland E, et al., the natural history of bacteriuria in childhood. Infect Dis Clin North Am. 1997; 11: 417-422.

Hizbullah Jan, Ismail Akbar et al., Frequency of Renal Stone Disease In Patients with Urinary Tract Infection. J Ayub Med coll Abbottabad 2008; 20(1).

Hodson CJ, Maling TM, McManamon PJ, et al., The pathogenisis of reflux nephropathy [chronic atropic pyelonephritis]. Br J Radiol., 1975; 48: 1.

Holden NJ, Totsika M, M ahler E, et al., Demonstration of regulatory cross -talk between $\mathrm{P}$ fimbriae and type I fimbriae in uropathogenic Escherichia coli, 
Microbiology. 2006; 152; 1143-1153. Huang WC, wann SR, Lin SL, et al., Catheter -associated urinary tract infections in intensive care units can be reduced by prompting physicians to remove unnecessary catheters. Infect Control Hosp Epidemiol 2004; 25; 974.

Hull RA, Hull SI. Nutritional requirements for growth of uropathogenic Escherichia coli in human urine, Infect Immun.1997; 65; 1960-1961.

Juthani-Mehta M, Asymptomatic bacteriuria and urinary tract infections in older adults. Clin Geriatr Med 2007; 23: 585594.

Kass EH. Asymptomatic infections of the urinary tract. Trans Assoc Am Phys 1956; 69:56.

Konemans colour atlas and text book of diagnostic Microbiology page 82-85.

Mackie and Mc Cartney, practical Medical Microbiology Cha 5, 6, 7. Pp. 95-150.

Mahesh.E et al., Ramesh. D, Indumathi V.A, Punith K, Kirthi Raj and Anupama H.A, Complicated urinary tract infection in a tertiary care center in South India. Al Ameen J Med Sci, Volume 3, No. 2, 2010.

Manik C. Shill, Naz H.HUDA et al., Prevalence of Uropathogens in Diabetic
Patients and Their Corresponding Resistance Pattern: Result of a survey Conducted at Diagnostic Centers in Dhaka, Bangladesh., Oman Medical Journal 2010, Volume 25, Issue 4.

Rayfield EJ, Ault MJ, Keusch GT, et al., Infection and diabetes; a case for glucose control. Am J Med 1982; 72: 439.

Ronald A, The etiology of urinary tract infection; traditional and emerging pathogens. Am J Med. 2002; 113(suppl IA):14S-19S.

Ronald AR, Pattullo AL. The natural history of urinary infection in adults. Med Clin North Am. 1991; 75:299-312.

Rubin RH. Infection in the renal and liver transplant patient. In: Rubin RH, Young LS, eds. Clinical approach to infection in the compromised host, 2nd Ed. New York: Plenum Press, 1988; 557.

Sibi.G, Aheibam Premita Devi, et al., Prevalence, Microbiologic profile OF Urinary Tract Infection and its Treatment with Trimethoprim in Diabetic patients. Research Journal of Microbiology 6 (6): 543-551, 2011.

Wheat LJ. Infections and Diabetes mellitus. DiabetesCare 1980; 3; 187.

\section{How to cite this article:}

Natesan, B. and Thasneem Banu. 2017. A Study on Bacteriological Profile of Urinary Tract Infection in Diabetes Mellitus Patients in a Tertiary Care Hospital. Int.J.Curr.Microbiol.App.Sci. 6(7): 2577-2583. doi: https://doi.org/10.20546/ijcmas.2017.607.304 